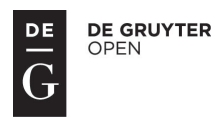

\title{
Methodology FOR THE SELECTION OF COMPENSATION TRADE TOOLS IN SMES
}

\author{
František Milichovsk $\dot{y}^{1}$, Jiří Koleňák ${ }^{2}$
}

\begin{abstract}
The main aim of this paper is to determine which factors of business tools are important in Czech companies. To find these factors, theoretical information from the area of trade tools and data from primary research (obtained via questionnaire) were used. These data are applied by a statistical evaluation of selected indicators which could help determine the significance of the indicators in the area being monitored. Activities concerning the management of company finances are also partially incorporated, as due to their close cohesion with business, they cannot be excluded from the field of turnaround management. The business tools described in the paper see excellent usage not only during times of crisis but also in periods of prosperity, when their application provides companies with unique competitive advantages as a way of increasing GDP. The results of the paper confirm the necessity for compensation tools in the business environment and provide the significance level of the compensation tools used. Accurate usage could create an advantage in a global market characterised by high competition.
\end{abstract}

\section{Keywords}

Compensation Trades, Trading Tools, Crisis Management, SMEs

\section{Introduction}

The topic of this paper is compensation trade tools that can help a company organize dayto-day activities in order to achieve strategic goals during an economic crisis. The tools that are used can be taken as kinds of performance indicators. The performance of these tools has become crucial in competitive struggles; they provide a competitive advantage and it should therefore be in the interest of enterprises to monitor these key indicators and factors.

\footnotetext{
${ }^{1}$ Brno University of Technology, Faculty of Business and Management, Kolejní 2906/4, 612 00 Brno, Czech Republic. E-mail: milichovsky@fbm.vutbr.cz.

2 Newton College, Politických vězňů 912/10, 11000 Praha, Czech Republic, E-mail: kolenak@newtoncollege.cz.
} 
Each economic crisis which has affected the European region raises important questions about the necessity of innovation to deal with the situation. This in turn creates opportunities for a company to be more effective in the monitoring of its own production and processes (Klímková, Hornungová, 2012).

The current hyper-competitive business environment requires continuous effort on the part of managers responsible for corporate governance to seek out new competitive advantages. In the recent past, inspiration has been found in the economic crisis, which forced the examination of the viability of projects and entire companies, and created a need to test management procedures and methods in the context of new circumstances.

Periods of crisis have given companies an opportunity to adapt to the business environment. Common practices include (1) reducing debts to the minimum (minimizing the risk of default) and (2) cost minimization and the stabilization of operating cash flow, methods which are commonly used by corporate top management. Financial and business instruments were applied alongside these tools.

This paper also deals with sets of business tools that help companies to realise their business and strategic objectives by means of compensation tools. The use of these is possible at any time, not only during periods of crisis. The aim of this paper is to find trends indicating improvement through the use of business tools during periods of economic crisis.

With regard to the state's provisions to deal with the crisis, small and middle companies are often on the edge of interest, even though they represent more than $99 \%$ of all companies and they make up more than two-thirds of all workplaces in the EU. They are the engine of innovation in lower orders and a platform for the development of the entrepreneurial spirit. Their obvious flexibility is perhaps the reason for the expectation that they will help themselves. The most important task for management is thus to find and realise provisions for stabilization and, if possible, to use the situation to improve the situation for the company. The tools available to managers in these conditions could be generally classified as crisis-management tools, but ultimately as turnaround-management tools.

\section{Theoretical background}

During any crisis, creative and innovative thinking become more important. According to Čichovský et al. (2012) and Vlček (2011), innovative thinking is created out of individual experiences and the ambition to improve abilities, skills or knowledge. Three factors are important for this creative process:

1) acceptance (usage of new and innovative findings in human thinking),

2) application (adoption or imitation of new and innovative findings),

3) adaptation (activity to transform findings into new original areas to expand knowledge).

Therefore, there exists a requirement to change the approach and thinking of entrepreneurs in order for them to be effective and innovative.

The effective implementation of innovation helps to increase competitiveness. It involves using intervention programs compared to free development and innovation under pressure. 
In each organisation, the implementation of innovation is accompanied by a lack of connectivity between individual areas and non-linearity. This is usually caused by a shortage of needful skills, scarce resources, low flexibility or poor education levels (McAdam, 2005).

Acceptable solutions could be used by so-called innovative thinking. In order for an implementation process to be successful with innovative thinking, an appropriate supportive organizational structure is required (Humpreys, McAdam, Leckey, 2005; Paul, Elder, 2002).

For many companies, hard times are a constant of the present period. The difficult situation on the market indisputably has a strong influence upon these companies. But it does not have to bring them to the brink of survival. There are many tools for the identification of approaching troubles and, if potential problems are discovered in time, appropriate tools can be used to master the situation.

There are many indicators which allow companies to recognise approaching difficulties. The relevance of the indicators differs between various fields and also between various companies. The basis should be tools for the strategic analysis of corporate surroundings: (1) PEST analysis of environmental influences, (2) five forces analysis, (3) the life cycle model (Johnson, Scholes, Whittington, 2008) and also of internal forces and environment value chain, value system, competitive advantages (Porter, 2008). Many suitable indicators could also be selected from models of company processes and from strategic and operative controlling (Steinstöcker, 1998).

In addition to the listing of single indicators, it is also necessary to consider their quantifying ability (some indicators are so-called soft indicators) and also with "decontamination" from relations to others, unrelated trends, cyclic and seasonal deviations, etc.

For the purposes of this paper, indicators of economic crisis status were mainly selected from the business field which monitor changes in demand volume and structure, availability of resources at the input (materials and raw material) and basic associated services. In the financial field, data were investigated about the availability of external financial resources, the payment discipline of customers and the ability to cover their obligations.

For the requirements of the research, tools were selected which help the exercise of control over cash flow (Castor and Newcomb, 2006), for example, provisions for the quicker recovery of debts, postponement of obligations maturity, the use of compensation businesses and also many exclusive business tools from the fields of marketing, promotion, relationships with customers or the development of business channels (MacPherson, Miller, 2010).

Many of the tools described can act in contrary ways and it depends only on the given situation and management attitude if the path out of the crisis will be, for example, the limitation of loyalty actions for constant customers or their development. From the point of view of crisis management, it is essential to take this situation into consideration and evaluate the pros and cons of both attitudes.

From the point of view of those activities realised during a crisis, strategic partnership enables companies, with minimal effort and fast diversification of their portfolio, to extend their services or distribution channels and thus should also be mentioned (Somnath, 
Pradyot, Sanjit, 2003; Koleňák, 2008; Oliver, Mpinganjira, 2011a). But the basic role of so-called turnaround management is played by compensation trade forms, especially barter and multilateral barter. In fact, barter trade is a general tool, applied in various countries (Oliver, Mpinganjira, 2011b).

Pure barter is the direct exchange of goods for goods, where one contract is signed for both supply and counter-supply. There is no invoicing in either the supplier's or the customer's currency, and there is no movement of money. Multilateral barter is quite a modern form of barter trade involving many parties. The fundamental basis of multilateral barter is that a client buys from another client goods or services only according to customer needs and pays by supplying his products to other clients. Individual businesses are not bound by a time frame; it is possible to purchase and sell continuously according to their needs. Each transaction is made by means of, and with support from, some barter centre. These subjects - trade companies of varying legal form and size, count of clients, turnover, and field of activity - register and book single transactions and are supported by the mutual business of their clients, participants in the corresponding barter chain with various means (Guriev, Ickes, 1999; Oliver, Mpinganjira, 2011a; Kaikati, Kaikati, 2013).

The main reason to use counter trade tools is in cases where companies are in a position where they must offer goods in return for an unstable local currency. Counter trades thus become a kind of guarantee of the value of the goods (Hatten, 2012; Marin, Schnitzer, 2002).

In times of crisis, a strong correlation exists between barter trades and business cycles, caused by the amount of barter transactions. Marvasti and Smyth (2011) and Cresti (2003) carried out studies in the U.S. region focusing on behaviour in barter exchanges between commercial barter and corporate barter. Both of these barter types are positively correlated with business inventories. That means companies usually use barter trades in almost $30 \%$ of all world trade cases (Oliver, Mpinganjira, 2011a).

In the Czech Republic, more than ten barter companies are active. Participation in the barter system can, for many entrepreneurs, be an interesting way to finance the overheads connected with the operation or extension of a company - especially in the current difficult period, when nearly every company is struggling with unbalanced cash flow. In the Czech Republic, fewer than 2,000 companies are actively organized in multilateral barter systems. In spite of all the arguments supporting the use of barter, there are many opponents declaring that there are not that many business cases wherein barter could substitute for classical payment with money. In reality, there is a problem with this claim, in that most of the transactions made via barter trade would not be made otherwise, or would only be of incomparably small volume or include other limitations.

One of the biggest problems entrepreneurs have to solve today is redundant capacity in the form of unused production facilities or the gathering of goods in stores (Uijttenbroek, 2004). These surplus products mean dead money, which is thus lacking from cash flow and which could be used by barter trade for the further development of the company. Barter trade thus helps to bring the actual state of assets in line with the desired state. When used, compensation tools contribute to improving corporate effectiveness. Hornungová (2014) mentioned possible systems by which management could measure the effectiveness 
of corporate activities in connection to national and international competitiveness and economic performance.

\section{Methodology}

The objective of this paper is find trends of improvement in the use of business tools in the course of, and after, periods of economic crisis. A questionnaire was used which focused on small and medium companies after the economic crisis (in 2013). Zbortková (2014) and Bishop (2013) supposed that the economic crisis finish before 2013, due to the increasing trend of the world economy.

The respondents to the questionnaire were mainly owners and managers. Companies for the survey which operate in the Czech Republic. The conditions for selection were as follows:

- Czech companies,

- corporate size of up to 250 employees.

Corporate size is based on the definitions in the user guide of the European community. This user guide includes limits on which companies can be divided into specific size groups (Evropské společenství, 2006). The main limits for individual groups are mentioned in Table 1.

Table 1: Limits for dividing companies

\begin{tabular}{|l|cccc|}
\hline & Number of employee & Annual turnover & & Annual balance \\
\hline Micro company & $<10$ & $\leq 2 \mathrm{mil} . €$ & or & $\leq 2 \mathrm{mil} . €$ \\
Small company & $<50$ & $\leq 10 \mathrm{mil} . €$ & or & $\leq 10 \mathrm{mil} . €$ \\
Medium company & $<250$ & $\leq 50 \mathrm{mil} . €$ & or & $\leq 43 \mathrm{mil} . €$ \\
\hline
\end{tabular}

Source: Evropské společenství, 2006

Questions were included as to how managers of SMEs are prepared to adapt their companies according to the impact of a crisis. The base premise was that managers have a low level of knowledge about trading tools.

Additional research methods were used to answer the primary objective of the research. From the point of view of secondary research, current information sources published in specialised literature were used, with a focus on tools from the field of business. In the primary research, we asked questions of the managers of Czech small and middle companies in the questionnaire and in some cases through controlled interviews.

The questionnaire used for primary investigation was divided into four categories:

1) Identification of the company

2) Impacts of the crisis on the business field

3) Impacts of the crisis on the financial field

4) Knowledge and usage of the tools for company management in times of crisis, with a stress upon protecting business activities (for more details, see the theoretical outcomes section). 
It was independently investigated as to whether the managers of small and middle companies have enough information and knowledge in this field and how they have acquired this knowledge. In accordance with the defined research, part of the primary research was focused on determining the development of knowledge in the field of compensation trade tools.

The questionnaire was carried out in the second half of 2013 and was focused on analysing the possible impacts of the economic crisis on companies. This exploration was executed on a sample of 242 respondents. The respondents were managers from various levels of corporate management.

The field of activity of each company can be placed into the fields of services, production, and the construction industry. It was important for our own research to determine whether the respondents use trading tools. Specific information about individual companies and their industry was not the essence of the research.

From the total count, the biggest group (more than 69\% overall) included owners or chief executives. Almost $15 \%$ of the rest of the respondents were located in lower management levels, and only $16 \%$ of respondents were in medium management.

\section{Results}

It is obvious from an analysis of the results that companies commonly use compensation trade tools as a potential business support. Based on the analysis of the statistical characteristics of the examined group, we will present our conclusions as an approximate result, limited by the resulting reliability. In the results of the paper there are characteristics of research barriers and future research possibilities.

Table 2 includes fundamental data which shows that it is clear that companies mainly use the following methods out of the group of compensation trade tools: Reducing the cost of procuring inputs; Minimization of warehouse stock. The conclusions are given by the characteristics of the limits of the research and its possible future direction.

Based on the analyses of descriptive statistical characteristics of the sample, our conclusions will be presented as an explorative result limited by the resultant reliability.

From an analysis of the basic descriptive statistics, it is clear that companies mainly use the following compensation trade tools:

- Reducing the cost of procuring inputs

- Minimization of warehouse stock

- Sale of surplus property

- Increasing awareness of production

Factor analysis reveals the reduction of surveyed corporate performance indicators which companies use in their own measurement processes. The main input into factor analysis was a correlation matrix which showed the individual correlation values of the chosen indicators (see Table 3). 
Based on the values listed in Table 3, it is possible to say that correlations exist only in the three highlighted relations. These relations are:

- Minimization of warehouse stock and Equal utilization of production capacities $(0,441)$,

- Increasing awareness of production and Equal utilization of production capacities $(0,419)$,

- Increasing awareness of production and Reducing the cost of procuring inputs $(0,430)$,

Thus only the following can be determined to be key tools: (1) Minimization of warehouse stock, (2) Equal utilization of production capacities, (3) Increasing awareness of production, and (4) Reducing the cost of procuring inputs.

Table 2: Basic descriptive statistics

\begin{tabular}{|l|ccc|}
\hline & Mean & Standard deviation & Variance \\
\hline Equal utilization of production capacities & 0.47 & 0.676 & 0.457 \\
Minimization of warehouse stock & 0.58 & 0.711 & 0.505 \\
Sale of surplus property & 0.51 & 0.665 & 0.442 \\
Reducing the cost of procuring inputs & 0.85 & 0.731 & 0.534 \\
Deleveraging of company & 0.39 & 0.639 & 0.408 \\
Increasing awareness of production & 0.52 & 0.677 & 0.458 \\
\hline
\end{tabular}

Source: Own work

Table 3: Correlation matrix

\begin{tabular}{|l|c|c|c|c|c|c|}
\hline & $\begin{array}{l}\text { Equal utili- } \\
\text { zation of pro- } \\
\text { duction ca- } \\
\text { pacities }\end{array}$ & $\begin{array}{l}\text { Minimization } \\
\text { of warehouse } \\
\text { stock }\end{array}$ & $\begin{array}{c}\text { Sale of sur- } \\
\text { plus property }\end{array}$ & $\begin{array}{l}\text { Reducing the } \\
\text { cost of pro- } \\
\text { curing inputs }\end{array}$ & $\begin{array}{l}\text { Deleveraging } \\
\text { of company }\end{array}$ & $\begin{array}{l}\text { Increasing } \\
\text { awareness of } \\
\text { production }\end{array}$ \\
\hline $\begin{array}{l}\text { Equal utiliza- } \\
\text { tion of pro- } \\
\text { duction capa- } \\
\text { cities }\end{array}$ & 1 & $0.441^{* *}$ & $0.188^{* *}$ & $0.382^{* *}$ & $0.130^{*}$ & $0.419^{* *}$ \\
\hline $\begin{array}{l}\text { Minimization } \\
\text { of warehouse } \\
\text { stock }\end{array}$ & $0.441^{* *}$ & 1 & $0.347^{* *}$ & $0.354^{* *}$ & 0.044 & $0.311^{* *}$ \\
\hline $\begin{array}{l}\text { Sale of sur- } \\
\text { plus property }\end{array}$ & $0.188^{* *}$ & $0.347^{* *}$ & 1 & $0.323^{* *}$ & $0.193^{* *}$ & $0.283^{* *}$ \\
\hline $\begin{array}{l}\text { Reducing the } \\
\text { cost of pro- } \\
\text { curing inputs }\end{array}$ & $0.382^{* *}$ & $0.354^{* *}$ & $0.323^{* *}$ & & $0.173^{* *}$ & $0.430^{* *}$ \\
\hline $\begin{array}{l}\text { Deleveraging } \\
\text { of company }\end{array}$ & $0.130^{*}$ & 0.044 & $0.193^{* *}$ & $0.173^{* *}$ & & 1 \\
\hline $\begin{array}{l}\text { Increasing } \\
\text { awareness of } \\
\text { production }\end{array}$ & $0.419^{* *}$ & $0.311^{* * *}$ & $0.283^{* *}$ & $0.430^{* * *}$ & $0.221^{* *}$ & $0.221^{* *}$ \\
\hline
\end{tabular}

Notes: * Correlation is significant at the 0.05 level

** Correlation is significant at the 0.01 level

Source: Own work 
Table 4: Rotated component matrix

\begin{tabular}{|lcc|}
\hline & Factor of production & Factor of finance \\
\hline Equal utilization of production capacities & 0.763 & 0.020 \\
Minimization of warehouse stock & 0.781 & -0.085 \\
Sale of surplus property & 0.455 & 0.462 \\
Reducing the cost of procuring inputs & 0.670 & 0.281 \\
Deleveraging of company & -0.016 & 0.918 \\
Increasing awareness of production & 0.636 & 0.358 \\
Cronbach's alpha & 0.718 & 0.323 \\
\hline Extraction Method: Principal Component Analysis. \\
Rotation Method: Varimax with Kaiser Normalization. Rotation converged in 3 iterations. \\
\hline Source: Own work
\end{tabular}

The total variance of inputs in the factor analysis can be explained by means of a description of the process of extraction. The beginning of extraction (Initial Eigenvalues) includes whole components which were put into the extraction. In the second step (Extraction Sums of Squared Loadings), according to the key (Eigenvalue $\leq 1$ ), there is a reduction to the four strongest components which are used in the next step of processing. The last step (Rotation Sums of Squared Loadings) shows the differences in individual components.

From this point of view, Extraction Sums of Squared Loadings with cumulative percentage is important. Factor analysis extracted only two factors, which explains almost $60 \%$ of the variance (the exact amount was 58.12\%). This result confirms the good factor result of the interpreted variance.

The total variance of the compensation trade tools are explained due to eigenvalues, which represents the total variance explained by each factor. In extraction, all components were divided into two new strongest component groups. These new component groups have diverse depth with the previous four components (see Table 4). The eigenvalues were determined by our own figures and only two components have figures over or very close to 1 . That means only two components make up almost $60 \%$ of the total variance of all four components, and have variability as original factors.

\section{Discussion}

In order to assess whether it is possible to use factor analysis, the Kaiser-Meyer-Olkin method (KMO) and Bartlett's test of sphericity were used. The KMO method is based on selective correlation and partial correlation coefficients. The value range of KMO is between 0 and 1 (Hinton, Brownlow, McMurray, Cozens, 2004). Each variable correlates perfectly with itself (approximate to 1), but has no correlation with the other variables (approximate to 0 ). In our case KMO reached a value of 0.752 , which means that the performed level of usefulness of factor analysis is at an average level.

Bartlett's test of sphericity is a statistic test that is used to examine the hypothesis that the variables are correlated or uncorrelated. No correlation was found with other variables $(\mathrm{Sig}=0.000)$. Nevertheless, Bartlett's test of sphericity is significant because of the value, which is lower than 0.05 . 
For the correctness of the factor analysis and acceptance the results, it is important to get a Cronbach's alpha value of over 0.7. Otherwise, there are requirements to improve the sample, or the questionnaire. Cronbach's alpha is a measure of internal consistency that is closely related to a set of items as a group. A "high" value of alpha is often used (along with substantive arguments and possibly other statistical measures) as evidence that the items measure an underlying (or latent) construct.

However, a high Cronbach's alpha does not imply that the measure is unidimensional. If, in addition to measuring internal consistency, you wish to provide evidence that the scale in question is unidimensional, additional analyses can be performed. Exploratory factor analysis is one method of checking dimensionality. Cronbach's alpha is not a statistical test; it is a coefficient of reliability (or consistency).

It could be written as a function of the number of test items and the average inter-correlation among the items. Below, for conceptual purposes, we show the formula for the standardized Cronbach's alpha:

$$
\alpha=\frac{N \times \bar{c}}{\bar{v}+(N-1) \times \bar{c}}
$$

where

$N$ is equal to the number of items,

$\bar{c}$ is the average inter-item covariance among the items,

$\bar{v}$ equals the average variance.

If the values were to increase the number of items $(N)$, it is possible to increase Cronbach's alpha. Moreover, if the average inter-item correlation is low, the alpha will be low. As the average inter-item correlation increases, Cronbach's alpha increases as well. The values of Cronbach's alpha could be from 0 to 1 . If the values were close to 0.5 , it signifies a bad level of internal consistency. Over 0.7 means that the value is acceptable and values close to 1 are excellent (Hinton, Brownlow, McMurray, Cozens, 2004).

According to our results, the values of Cronbach's alpha were:

- Factor of production is at a good level

- Factor of finance is unacceptable.

Calculating the final value of acceptable factors needs the transformation of individual coefficients. These coefficients have become the significance of used elements. Their sum total has to be 1 . The index of the factor of production was defined by this procedure.

$$
\begin{aligned}
& \text { index of production factor }= \\
& \qquad 0,268 \times E+0,274 \times M+0,235 \times R+0,2223 \times I
\end{aligned}
$$

where

$E-$ Equals utilization of production capacities

$M-$ Minimization of warehouse stock

$R$ - Reducing cost of procuring inputs

$I$ - Increasing awareness of production 
On the basis of the calculation index of the factor, the mean value of the index was found. This value represents the average factor for each set of data recorded. We can say that these indices reflect low bonds within a factor. This is due to the range of possible answers listed in the questionnaire.

Table 5: Evaluation of observed factor

\begin{tabular}{|l|ccc|}
\hline & Mean & Standard deviation & Variance \\
\hline Index of production factor & 0.5972 & 0.51511 & 0.265 \\
\hline
\end{tabular}

To modify the index, it is necessary to use a rating scale for companies which determines whether the tool is used. For the calculation of the total index, it is necessary to put the answers of individual respondents into the appropriate index formula.

\section{Conclusion}

The stated results confirm the necessity for compensation tools in the business environment and detect the lack of using these tools, especially during times of crisis. These tools could create an advantage in a global market characterized by high levels of competition.

The application of compensation tools in an effective manner supports corporate economic health, market position, and ultimately an increase in the GDP of the Czech Republic.

Post-crisis, individual governments approached anti-crisis policies with the obvious goal of limiting the negative influence on their economies. Zich (2009) mentions that the political situation itself offers the theme of the influence of links formed by various stakeholders in the competitive space upon the possibility of the development of company competitiveness and the ability to succeed. A similar opinion is put forth by Tomek and Vávrová (2009). Applied accurate policy by government should create opportunities for domestic companies to expand abroad (Lin, Cheng, 2013).

The correct choice of accurate compensation trade tools has become an important part of the corporate strategic process.

A limitation of this paper is its focus on only domestic Czech companies. It is therefore necessary to carry out future research where it is possible to use knowledge not only in the domestic environment, but in the international environment, and to ascertain the influence of economic "hard" times (e.g. on the European Union and Visegrad group).

Despite this, great progress has been made in the understanding and utilization of the findings and experience with marketing management by companies in the Czech environment. Our research showed that there is great room for improvement and offers new ways for companies to be more competitive. 


\section{References}

Bishop, K. (2013). The global financial crisis is over. World economy. Retrieved from http://www.cnbc.com/id/101231654.

Castor, R., Newcomb, T. (2006). From RED to BLACK: rebuilding wounded companies. Financial Executives International, 22(1), 1-26.

Cresti, B. (2003). U.S. domestic barter: An empirical investigation. Applied Economics, 37(17), 1953-1966.

Čichovský, L., Boháček, J., Urban, J. (2012). Moderní pojetí inovací a jejich typologií pro praxi. Praha: VŠEM.

Evropské společenství. (2006). Nová definice malých a středních podniků: Uživatelská příručka a vzor prohlášení.

Guriev, S., Ickes, B. (1999). Barter in Russian enterprises: Myths vs. Empirical Evidence. Russian Economic Trends, 8(2), 6-13. Doi: 10.1111/1467-9426.00046.

Hatten, T. S. (2012). Small Business Management: Entrepreneurship and beyond. 5th ed. Mason: South-West Cengage Learning.

Hinton, P. R., Brownlow, C., McMurray, I., Cozens, B. (2004). SPSS Explained. East Sussex: Routledge.

Hornungová, J. (2014). Development of Concepts and Models of Performance Evaluation from the 19th Century to the Present. DANUBE: Law and Economics Review, 5(2), 143-154. Doi 10.2478/danb-2014-0008.

Humpreys, P., McAdam, R., Leckey, J. (2005). Longitudinal evaluation of innovation implementation in SMEs. European Journal of Innovation Management, 8(3), 283-304. Doi: 10.1108/14601060510610162.

Johnson, G., Scholes, K., Whittington, R. (2008). Exploring Corporate Strategy: Text \& Cases. Lombarda: Pearson Education.

Kaikati, A. M., Kaikati, J. G. (2013). Doing business without exchanging money: The scale and creativity of modern barter. California Management Review, 55(22), 46-71.

Klímková, M., Hornungová, J. (2012). Performance of Enterprises from Information and Communication Activities in Economic and Social Area. Trends Economics and Management, 6(12), 128-136.

Koleňák, J. (2008). Business alliances in economical crisis. Periodica Academica, 3(2), 35-40.

Lin, W. T., Cheng, K. Y. (2013). Upper echelon compensation, performance, and the rhythm of firm internationalization. Management Decision, 51(7), 1380-1401. Doi 10.1108/MD-04-2012-0291.

MacPherson, D., Miller, D. (2010). Break through Business Development: A 90-Day Plan to Build Your Client Base and Take Your Business to the Next Level. Mississauga: John Wiley and sons.

Marin, D., Schnitzer, M. (2002). Contracts in trade and transition: The resurgence of barter. Massachusetts Institute of Technology.

Marvasti, A., Smyth, D. J. (2011). Barter and business cycles: Further empirical evidence. The American Economist, 56(2), 85-97. 
McAdam, R. (2005). A multi-level Theory of innovation implementation: Normative evaluation, legitimisation and conflict. European Journal of Innovation Management, 8(3), 373-388. Doi: 10.1108/14601060510610216.

Oliver, P., Mpinganjira, M. (2011a). An empirical investigation into difficulties associated with barter trading: A practioner's perspective. African Journal of Business Management, 5(4), 1085-1092.Doi: 10.5897/AJBM10.086.

Oliver, P., Mpinganjira, M. (2011b). Barter trading: An empirical investigation of management practices. African Journal of Business Management, 5(31), 12256-12263. Doi 10.5897/AJBM11.273.

Paul, R., Elder, L. (2002). Critical Thinking. New Jersey: Upper Saddle River.

Porter, M.E. (2008). Competitive Advantage: Creating and Sustaining Superior Performance. Simon and Schuster.

Somnath, D., Pradyot, K. S., Sanjit, S. (2003). Strategic alliances: a valuable way to manage intellectual capital? Journal of Intellectual Capital, 4(1), 10-19. Doi 10.1108/14691930310 455351

Steinöcker, R. (1998). Strategický controlling. Praha: Profess Consulting.

Tomek, G., Vávrová, V. (2009). Jak zvýšit konkurenceschopnost firmy. Praha: C. H. Beck. Uijttenbroek, A. (2004). BDM Business Development Methodology: Core Processes. Lansa Publication.

Vlček, R. (2011). Strategie hodnotových inovací - tvorba, rozvoj a měřitelnost inovací. Praha: Professional Publishing.

Zbortková, J. (2014). Globální finanční krize je u konce. Čeká nás planetární hospodářská megaparty. CFOworld. Retrieved from http://cfoworld.cz/krize/globalni-financni-krize-jeu-konce-ceka-nas-planetarni-hospodarska-megaparty-2878.

Zich, R. (2009). Application and Development of Success-Ability Concept in Research of Company Competitive Advantage. In: Kocourek, A. (ed.) Proceedings of 9th International Conference Liberec Economic Forum 2009, 432-443. 